\title{
Response of individual shoaling Atlantic cod to ocean currents on the northeast Newfoundland Shelf
}

\author{
J.S. Wroblewski ${ }^{\mathrm{a}}{ }^{*}$, Bruce G. Nolan ${ }^{\mathrm{a}}$, George A. Rose ${ }^{\mathrm{b}}$, Brad deYoung ${ }^{\mathrm{c}}$ \\ ${ }^{a}$ Fisheries Oceanography Group, Ocean Sciences Centre, Memorial University of Newfoundland, St. John's, Nfld., Canada A1B 3X7 \\ ${ }^{\mathrm{b}}$ Fisheries Conservation Chair, Marine Institute, Memorial University of Newfoundland, St. John's, Nfld., Canada A1C 5R3 \\ ${ }^{c}$ Department of Physics and Physical Oceanography, Memorial University of Newfoundland, St. John's, Nfld., Canada A1B $3 X 7$
}

Received 26 January 1999; received in revised form 28 July 1999; accepted 16 August 1999

\begin{abstract}
The movements of sonically-tagged Atlantic cod swimming within a large $(80,000 \mathrm{mt})$ shoal of post-spawning fish on the northeast Newfoundland Shelf were related to the acoustically determined position of the shoal and event structure in the local ocean currents. For the first several days of the study, a period when currents were unfavorable for shoreward transport, the tagged fish maintained station. There was little net movement of individual fish and no change in the geographical location of the shoal. Then, apparently in response to a shoreward current event, the cod moved with the flow. The tagged cod behaved as members of the shoal, in that their net movement was similar to that of the shoal itself. These observations further support the hypothesis that cod on the northeast Newfoundland Shelf selectively use currents for transport during their shoreward feeding migration. The cue to initiate migration by post-spawning cod is apparently an organized onshore flow exceeding a threshold velocity and duration. (C) 2000 Elsevier Science B.V. All rights reserved.
\end{abstract}

Keywords: Atlantic cod; Gadus morhua; Swimming behavior; Current transport; Newfoundland Shelf

\section{Introduction}

Ocean currents can provide a transport mechanism and/or directional clues to marine fishes that undertake long distance migrations (Harden Jones, 1968; Arnold, 1981; Rose, 1993; Arnold and Metcalfe, 1995). Swimming with currents provides energetic benefits to fish migrating to their spawning ground, theoretically saving energy which can be used for reproduction (Weihs, 1978; Metcalfe et al., 1990).

*Corresponding author. Tel.: +1-709-737-2410; fax: +1-709737-8739.

E-mail address: jwroblew@morgan.ucs.mun.ca (J.S. Wroblewski).
There are also benefits for post-spawning fish which are in poor condition (Templeman, 1965; DeBlois and Rose, 1995). Plaice (Pleuronectes platessa), Atlantic cod (Gadus morhua) and other fish in the North Sea use tidal flows to facilitate their migrations in a mechanism called "selective tidal stream transport" (Arnold, 1974; Arnold et al., 1994). Rose et al. (1995) observed a shoal of post-spawning Atlantic cod on the northeast Newfoundland continental shelf respond to currents flowing shoreward toward their inshore feeding grounds. Flows along inshore-leading topography would provide migrating northern cod (Lear and Green, 1984; Rose, 1993) with directional clues to reach the northeast Newfoundland coast. 
We present here observations over a five-day period (29 June-3 July, 1992) of the movements of individual cod swimming within a shoal of cod studied acoustically by Rose (1993), Rose et al. (1995) and DeBlois and Rose (1995). Most investigations of individual fish movements within a shoal involve pelagic species under laboratory tank conditions (Pitcher et al., 1982; Robinson and Pitcher, 1989). We are unaware of any previous account of individual G. morhua moving within a shoal in the sea for which the overall movement of the aggregation is also known.

Sonic tagging (Hawkins and Urquhart, 1983; Arnold and Metcalfe, 1989) allows researchers to monitor continuously the swimming behavior of individual fish in the field. However, the difficulty of tracking sonically-tagged fish in the open ocean with a research vessel limits the number of animals which can be observed simultaneously. Fish can be released with data storage (archival) tags (Metcalfe and Arnold, 1997), but then the animals have to be recaptured or their data transmitted to a receiver. The track of the individual fish might then be reconstructed from the recorded data (e.g. temperature and depth), as interpreted from previous knowledge of the physical oceanographic environment. If sufficient oceanographic data exist for the region, the influence of currents on the track may be discerned (Arnold and Holford, 1995).

Large aggregations of fish can be tracked by sequential acoustic measures of shoal location (Rose, 1993; Rose et al., 1995), but it is difficult to resolve the movements of individual fish within the aggregation. By combining sonic tagging and tracking with acoustic mapping, we have determined the position of individual fish within this large, moving aggregation of cod on the Newfoundland Shelf. We use current meter data concurrent with the tracking experiment to calculate the swimming speeds and headings of tagged cod as the shoal began its migration to the Newfound- land coast. We test the hypothesis that an onshore current event provides a cue which initiates migration behavior.

\section{Materials and methods}

\subsection{Acoustic survey}

During 8 June-14 July 1992 a large $(80,000 \mathrm{mt})$ shoal of cod was tracked by vessels equipped with dual beam echo-sounders $(38 \mathrm{kHz})$ as the cod migrated inshore along the Bonavista corridor of the northeast Newfoundland Shelf (Fig. 1). Densities of cod were determined by standard integration techniques (MacLennan and Simmonds, 1992) every $0.1 \mathrm{~km}$. Details of the acoustic methods and surveying of the shoal are given in Rose et al. (1995) and DeBlois and Rose (1995). The method used to estimate biomass is presented in Rose and Kulka (1999).

\subsection{Sonic tagging and tracking experiment}

Cod from the shoal (Fig. 2) used for the tracking experiment conducted 29 June-3 July 1992 were caught on a long-line baited with squid (Illex illecebrosus) and set along the bottom (330-337 $\mathrm{m}$ depth) at $49.50^{\circ} \mathrm{N}, 50.66^{\circ} \mathrm{W}$. Bottom temperature was $3^{\circ} \mathrm{C}$. The fish were brought to the surface (ascent rate of $10 \mathrm{~m} \mathrm{~min}^{-1}$ ) and placed in a holding tank continuously replenished with near surface seawater of 4$5^{\circ} \mathrm{C}$. Cod adapted to deep water and raised to the surface may have greatly expanded or ruptured swim bladders, losing the ability to maintain neutral buoyancy (Harden Jones and Scholes, 1985; Arnold and Greer Walker, 1992). Therefore, only fish that appeared uninjured in the holding tank were selected for tagging. The cod which were tagged and released (Table 1) were large $(56-57 \mathrm{~cm})$ relative to the mean

Table 1

Length $(L)$, weight $(W)$ and Fulton's condition factor $\left(K=W / L^{3} \times 100\right)$ for sonically-tagged cod ${ }^{\text {a }}$

\begin{tabular}{llllll}
\hline Cod & $L(\mathrm{~cm})$ & $W(\mathrm{~kg})$ & $K$ & Heading $\left({ }^{\circ} \mathrm{N}\right)$ & \multicolumn{2}{c}{ Swim speed } \\
\hline 1 & & & & 121 & 0.18 \\
$\left(\mathrm{~m} \mathrm{~s}^{-1}\right)$ & 0.24 & 0.32 \\
3 & 57 & 1.8 & 0.97 & 143 & 0.14 \\
\hline
\end{tabular}

${ }^{\text {a }}$ Heading $\left({ }^{\circ} \mathrm{N}\right)$ and swimming speed $\left(\mathrm{m} \mathrm{s}^{-1}\right.$ and $\left.\mathrm{BL} \mathrm{s}^{-1}\right)$ calculated for cods $1-3$ during their southward movement shown in Fig. 5 . 


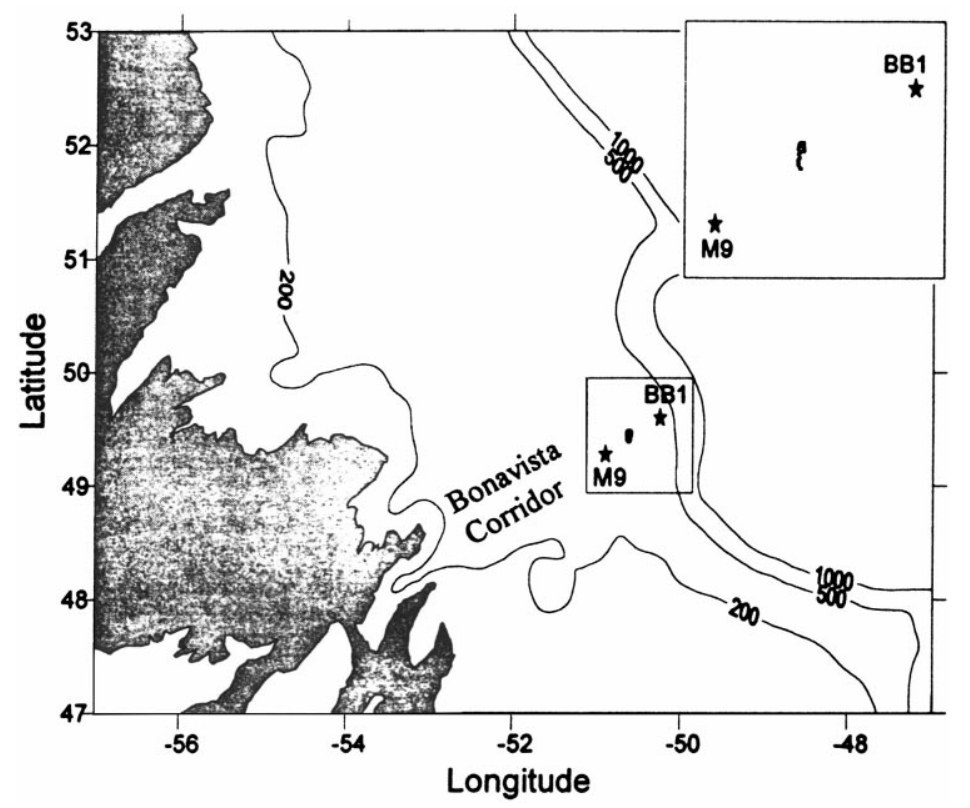

Fig. 1. Area of operations $\left(49.45^{\circ} \mathrm{N}, 50.63^{\circ} \mathrm{W}\right)$ for the sonic tracking experiment conducted on the northeast Newfoundland Shelf, 29 June-3 July 1992, and location of current meter moorings M9 and BB1. The cluster of points between BB1 and M9 are the tracks of cods 1-3.

size of cod within the shoal $(45 \mathrm{~cm}, 7.7 \mathrm{~cm}$ s.d., Rose et al., 1995).

A Vemco V3P-1H sonic tag $(62 \mathrm{~mm}$ long $\times 16 \mathrm{~mm}$ diameter, weighing $23.5 \mathrm{~g}$ in air) with a depth sensor (resolution in depth, $\pm 10 \mathrm{~m}$ ) was pushed past the esophagus and into the stomach of the fish using a wooden dowel (Hawkins and Urquhart, 1983). The fish was placed back into the holding tank for several minutes to ensure the tag was not regurgitated, and then released at the ocean surface. Approximately $3 \mathrm{~h}$ elapsed from time of capture to release. Tags transmitted predetermined high frequency pulses between 50 and $76 \mathrm{kHz}$. The transmitters emitted signals for approximately five days with a detection range of $1-2 \mathrm{~km}$.

Sonic tracking operations were carried out aboard the CRV Parizeau. Cod movements were monitored using a Vemco V-10 directional hydrophone attached to the end of a $6 \mathrm{~m}$ aluminum pole and held below the ocean surface. An additional hydrophone was attached to a V-fin depressor towed amidships of the tracking vessel. Transmitter signals were decoded into depth readings by a Vemco VR-60 receiver. On average fish position was recorded every $10 \mathrm{~min}$.
Fish position was taken as the vessel's Global Positioning System (GPS) coordinates where the strength of a transmitter signal was maximal. The successive positions defined the track of the fish relative to the sea-bed. Time was recorded as Greenwich Mean Time (GMT), which was local Newfoundland Standard Time $+2.5 \mathrm{~h}$.

\subsection{Current meter observations}

At the time of the tracking experiment, a grid of 10 moorings with Aanderaa RCM-4 current meters was in place along the Bonavista Corridor (Rose et al., 1995; Colbourne et al., 1997). 1 min averages of ocean temperature, salinity and current speed and direction were recorded every $30 \mathrm{~min}$ by each instrument. Data from the mooring M9 $\left(49.27^{\circ} \mathrm{N}, 50.89^{\circ} \mathrm{W}\right)$ were used in the analysis of cod movements, as this mooring was closest to the sonically-tagged fish (Fig. 1). Current meter M9 was approximately $30 \mathrm{~km}$ to the southwest of tracking operations. It was assumed that data from the M9 current meter at $315 \mathrm{~m}$ depth (15 $\mathrm{m}$ above the bottom) were representative of continental shelf currents in the immediate vicinity of the sonically-tagged 

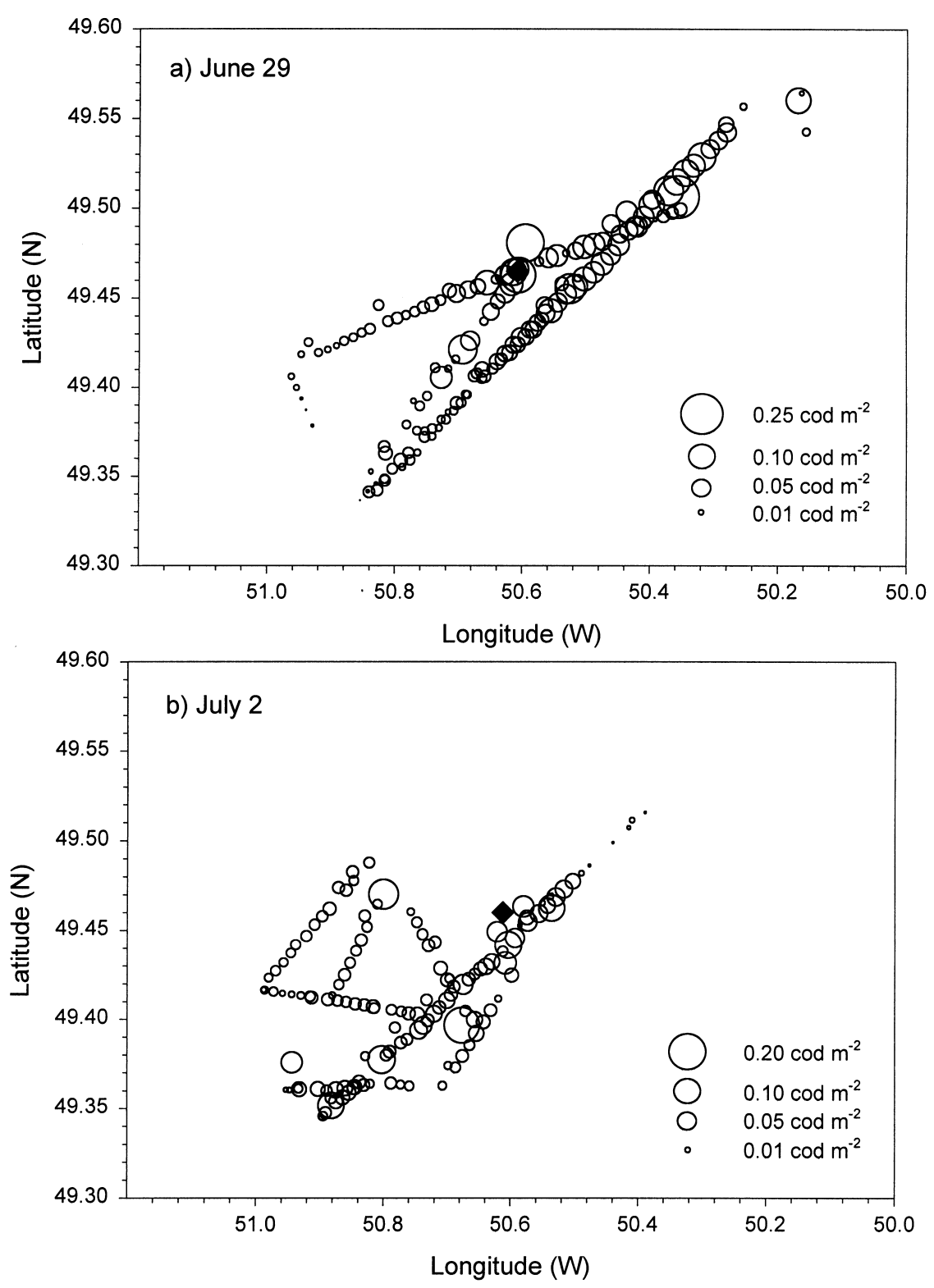

Fig. 2. Relative acoustic densities of cod and the position of sonically-tagged cods 1-3 (filled diamond): (a) within the shoal on 29 June and (b) 2 July 1992 .

cod. Swimming course (speed and direction) was calculated as the resultant of the M9 current vector and the track of the fish relative to the sea-bed (Hawkins and Urquhart, 1983; Arnold et al., 1994).

Concurrent information on flows occurring near the edge of the continental shelf was available from the mooring BB1 (Fig. 1) located at $49.59^{\circ} \mathrm{N}, 50.24^{\circ} \mathrm{W}$ (Narayanan, 1994; Colbourne et al., 1997). Data from BB1 include ocean temperature, salinity and north (u) and east (v) current components, recorded hourly by an Aanderaa RCM-5 current meter moored at $315 \mathrm{~m}$ depth. 

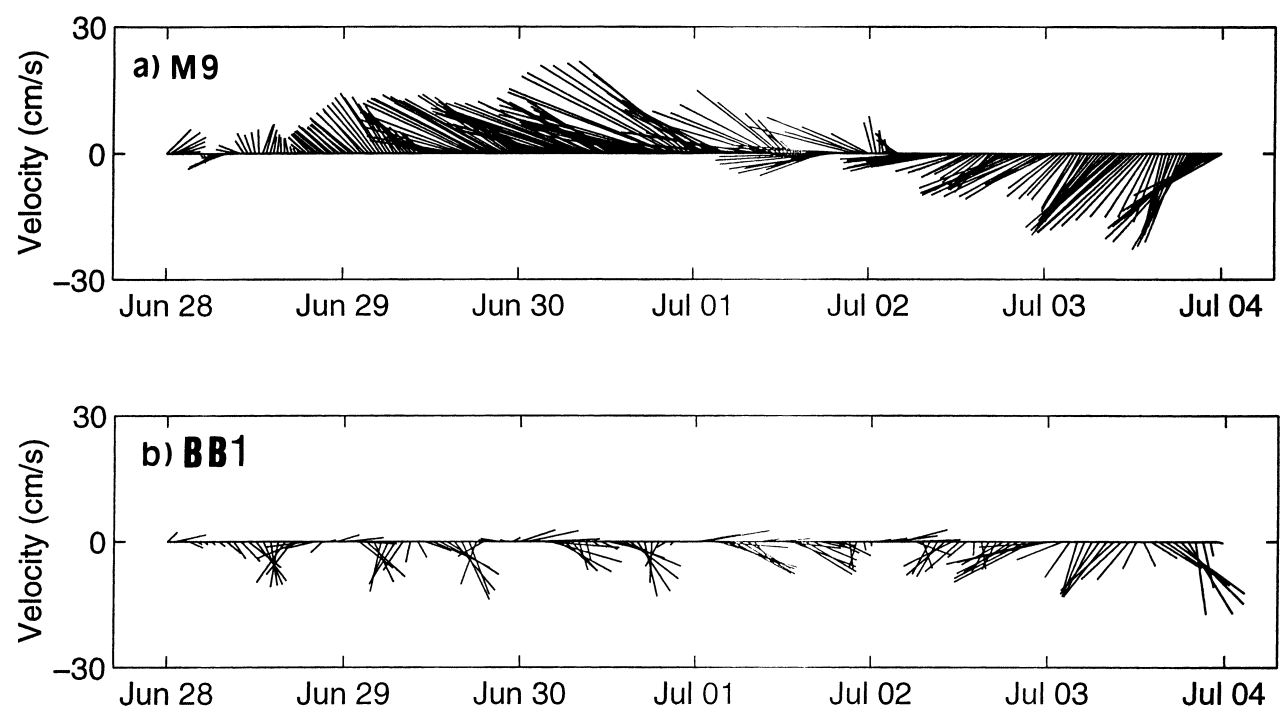

Fig. 3. Speed and direction of the near bottom currents at mooring M9 (a) and BB1 (b) during 28 June-4 July 1992.

\section{Results}

\subsection{Ocean currents, 28 June-4 July 1992}

Direction and velocity of the near bottom ocean currents 28 June-4 July at moorings M9 and BB1 are shown in Fig. 3. From 29 June until 2 July, M9 recorded a northwest current over the continental shelf. The flow near the shelf edge at BB1 was variable, but predominately to the south. On 2 July the M9 mooring recorded a change in direction of the current flow from the northwest to the southwest at about 05:00 hours. At both M9 and BB1 the current flowed to the south-southwest during 2-3 July.

\subsection{Cod maintained station in a northwest flowing current}

Sonically-tagged cod 1 released on 28 June at 22:34 GMT descended into the shoal (Fig. 2a) at a rate of $1.3 \mathrm{~m} \mathrm{~min}^{-1}$, reaching the bottom depth of $335 \mathrm{~m}$ at 03:00 hours on 29 June. Thereupon the fish moved in an undirected pattern along the bottom. During the first $15 \mathrm{~h}$ after descent the total distance traveled over the seabed was $12 \mathrm{~km}$, as computed by the successive addition of the straight line distances between fixes (Fig. 4). From 29 June to the morning of 2 July cod 1 did not drift with the northwest flowing current, but rather remained near the point of descent.
Cods 2 and 3 were released together at the surface on 29 June at 12:44 hours near the location of $\operatorname{cod} 1$ (Fig. 2a). Cod 2 descended at a rate of $5.7 \mathrm{~m} \mathrm{~min}^{-1}$. Cod 3 reached the bottom depth of $333 \mathrm{~m}$ at 13:35

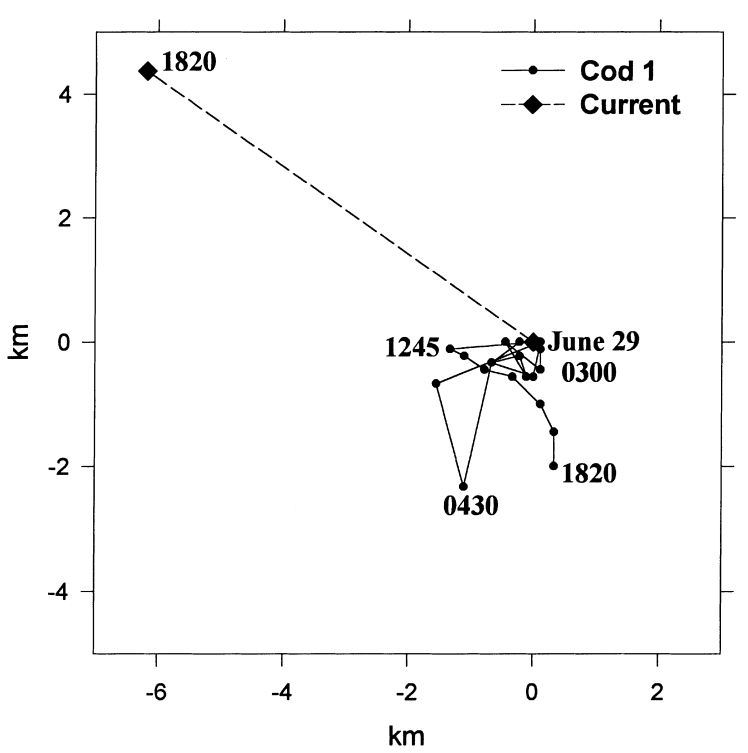

Fig. 4. Movements of cod 1 (solid line) on 29 June 1992. Dots indicate relocation positions. The dashed line predicts the displacement if cod 1 was drifting with the bottom current recorded at the M9 mooring. 
hours, a descent rate of $5.5 \mathrm{~m} \mathrm{~min}^{-1}$. The same undirected pattern of movements observed for cod 1 was also observed for cods 2 and 3 during 29 June-2 July. The general location of the shoal did not change between 29 June and 2 July (Fig. $2 \mathrm{a}$ and b). On the morning of 2 July cods 1,2 and 3 were all located within a high density area of the shoal, near their initial point of descent three days earlier (Fig. 2b).

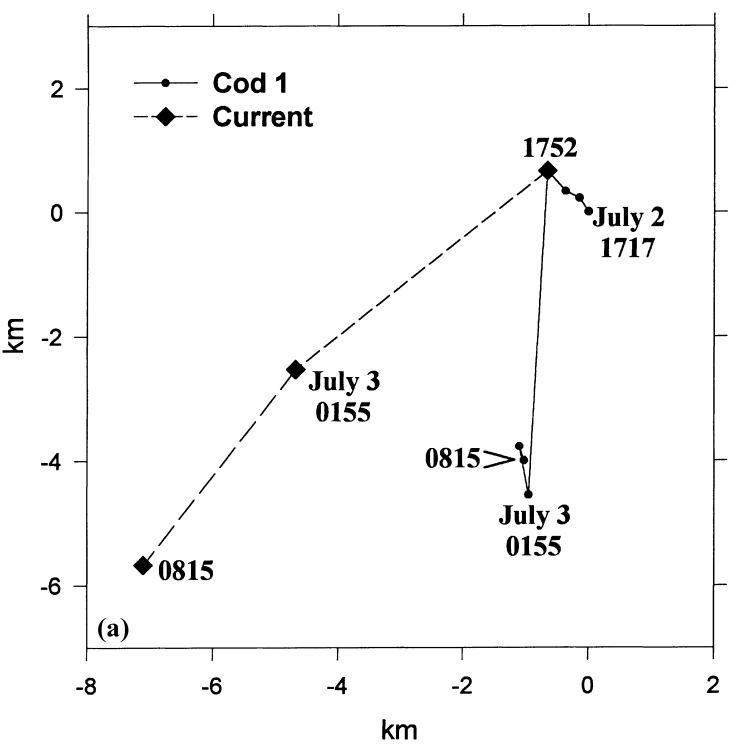

\subsection{Cod transported by an onshore current event}

The initiation of an onshore (southwest) current event was recorded at M9 early on 2 July, with the current intensifying throughout the day (Fig. 3a). At 17:52 hours on 2 July cod 1 began moving southsouthwest (Fig. 5a) and traveled a net distance of $5.3 \mathrm{~km}$ along the bottom during the next $8 \mathrm{~h}$. Vector
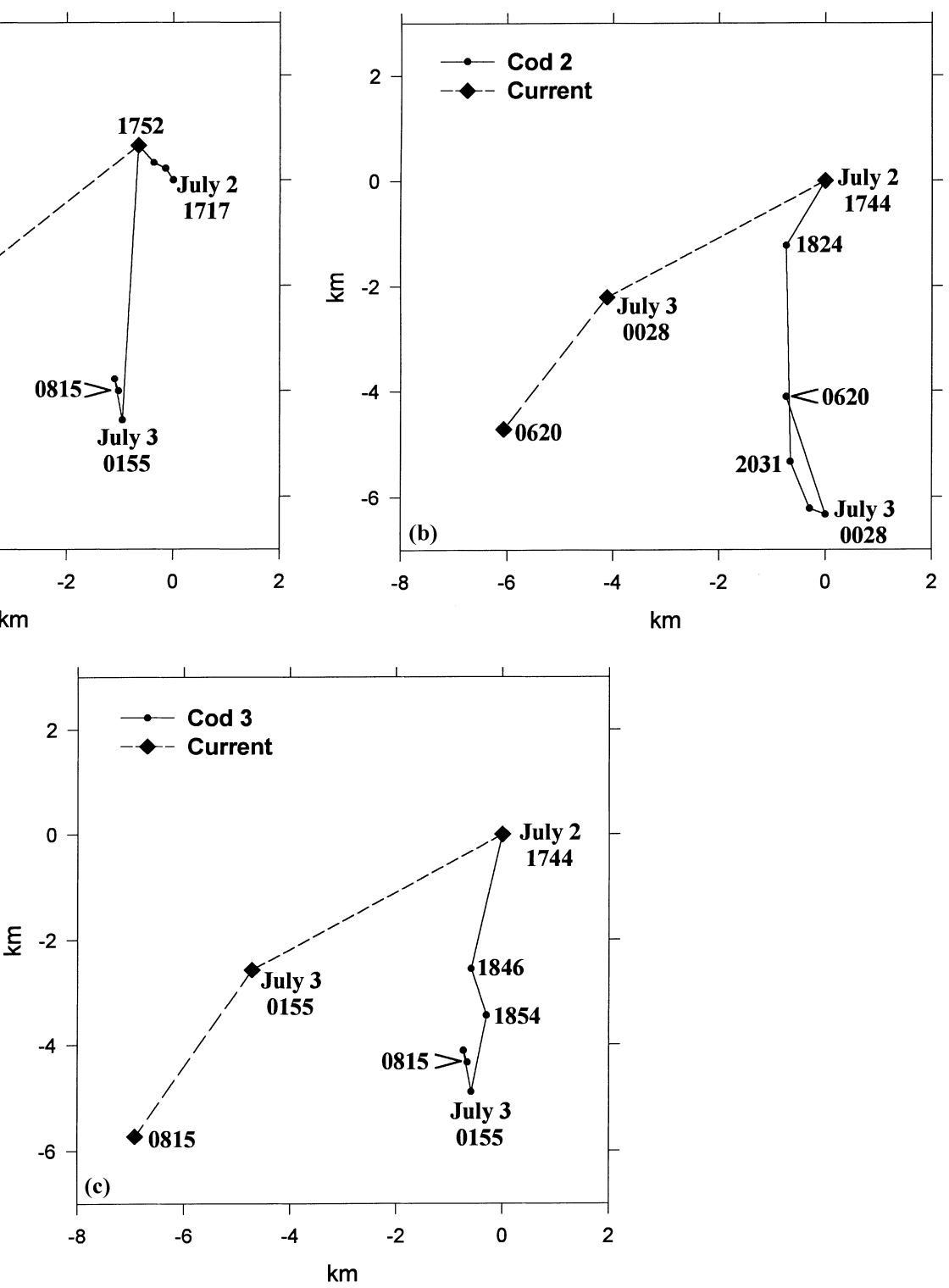

Fig. 5. Movements of $\operatorname{cod} 1$ (a), cod 2 (b) and $\operatorname{cod} 3$ (c) during 2-3 July 1992. The dashed line predicts the displacement if the fish was drifting with the near bottom current recorded at the M9 mooring. 
calculations indicate the fish swam through the water at a speed of $18 \mathrm{~cm} \mathrm{~s}^{-1}$ along a heading of $121^{\circ} \mathrm{N}$ (Table 1), as the fish was carried by the current $\left(17 \mathrm{~cm} \mathrm{~s}^{-1}\right.$, range $13-23 \mathrm{~cm} \mathrm{~s}^{-1}$; heading $228^{\circ} \mathrm{N}$ during this $8 \mathrm{~h}$ period). At 01:55 hours on 3 July, cod 1 ceased moving south, although the current continued to flow to the southwest at $>15 \mathrm{~cm} \mathrm{~s}^{-1}$ (Fig. 3a). Thereafter the fish appeared to move in no fixed direction. At 08:15 hours cod 1 could no longer be detected, presumably due to low battery power of the transmitter.

Cod 2 (Fig. 5b) exhibited a downstream movement similar to cod 1. At 17:44 hours on 2 July cod 2 began moving south, covering a net distance of $5.8 \mathrm{~km}$ during the next $7 \mathrm{~h}$. The calculated fish swimming speed was $24 \mathrm{~cm} \mathrm{~s}^{-1}$, along a heading of $143^{\circ} \mathrm{N}$ (Table 1). The swimming speed exceeded the current velocity (average $18 \mathrm{~cm} \mathrm{~s}^{-1}$ during this $7 \mathrm{~h}$ period). At 20:31 hours the depth telemetered by cod 2 was $218 \mathrm{~m}$. By 22:54 hours the fish had descended to the bottom $(330 \mathrm{~m})$. At 00:28 hours on 3 July cod 2 ceased moving with the southwest current.

Horizontal movements by cod 3 during the onshore current event (Fig. 5c) were similar to those of cods 1 and 2. Beginning at 17:44 hours on 2 July cod 3 moved south-southwest a net distance of $4.9 \mathrm{~km}$ along the bottom during the next $8 \mathrm{~h}$. The fish's swimming speed $\left(14 \mathrm{~cm} \mathrm{~s}^{-1}\right)$ and heading $\left(120^{\circ} \mathrm{N}\right.$, Table 1$)$ displaced it eastward relative to its passive drift trajectory (Fig. 5c). As observed for cod 1, cod 3 ceased moving with the current at approximately 01:55 hours. There was little net movement between 01:55 and 08:15 hours on 3 July when the tracking experiment was terminated.

\section{Discussion}

The sonically-tagged cod behaved similarly during the tracking period. For the first three days after release the tagged cod moved actively along the bottom, yet there was no net change in location while the current flowed to the northwest. Assuming the current in the vicinity of the fish was the same as that recorded at M9, a progressive vector diagram (Fig. 6) shows that the experimental fish and the shoal could have drifted $22 \mathrm{~km}$ to the north and $50 \mathrm{~km}$ to the west. However no displacement of the tagged fish or the shoal (Rose et al., 1995) was observed. Tytler et al.

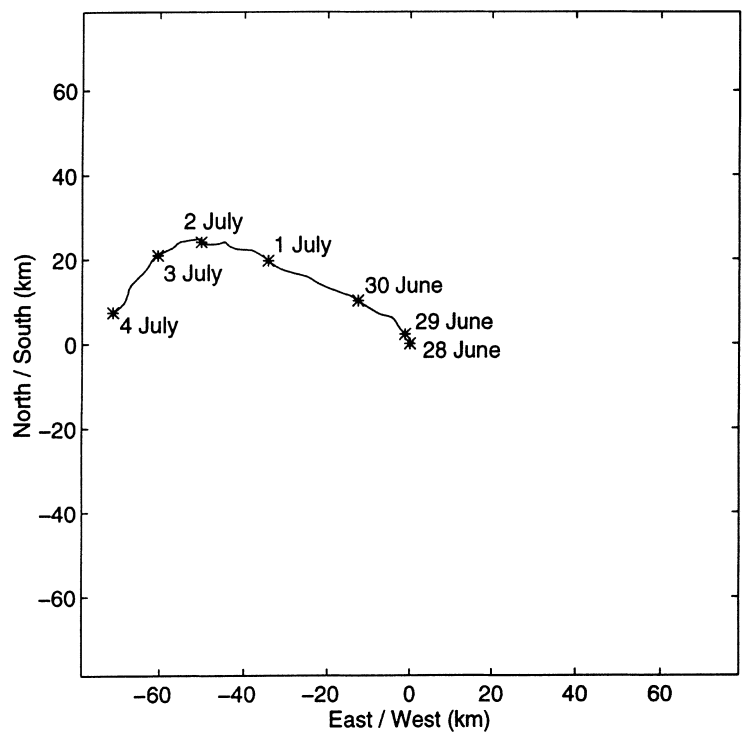

Fig. 6. Progressive vector diagram of the near bottom current at the M9 mooring during 28 June-4 July 1992.

(1978) suggest the turning behavior evident in Fig. 4 is a mechanism preventing dispersal from a center of activity.

On the fourth day of the study, the shoal (Fig. 2b) and all three tagged cod (Fig. 5) moved with the flow when the current turned shoreward (Fig. 3). What cue caused this change in behavior from nondirected to directed movement? The current meter data from both M9 and BB1 moorings indicate a strong onshore (southwest) flow extending from the shelf edge to the mid-shelf began early on July 2 (Fig. 3a and b). The southwest flow intensified throughout the day. There was a lag of approximately $12 \mathrm{~h}$ between the slack water prelude to the current event and the initiation of southward movement by the sonicallytagged cod. It appears that the onshore current event stimulated the directed movement exhibited by the fish. The cue may have been the current with a persistent velocity $\geq 10 \mathrm{~cm} \mathrm{~s}^{-1}$ (increasing to $23 \mathrm{~cm} \mathrm{~s}^{-1}$ ) flowing in the approximate direction of the mean migration route of cod along the Bonavista Corridor ( $198^{\circ}$ true north; Rose et al., 1995). The near bottom seawater temperature recorded at M9 increased slightly from $2.5^{\circ} \mathrm{C}$ to $2.7^{\circ} \mathrm{C}$ during the current event, while salinity increased from 34.7 to 34.8 ppt. 
Arnold et al. (1994) observed the feeding migration of sonically-tagged cod in the North Sea and suggested that cod utilize selective tidal stream transport to move toward their feeding grounds. Cod would oppose "unfavorable" tidal streams by swimming against them, or by descending to the sea-bed. When the tidal stream was flowing in a "favorable" direction (e.g. towards feeding grounds) cod would swim with these flows. In our study, cod stemmed the current when it flowed away from feeding grounds along the Newfoundland coast (Fig. 4). However, when currents reversed and began flowing shoreward towards Cape Bonavista (Fig. 1), the individual cod moved with the current (Fig. 5).

The cessation of directed movement by each tagged fish on the evening of 2 July (Fig. 5) was not due to a change in the current, which continued to flow in a southwesterly direction (Fig. 3). The time (00:2801:55 GMT on 3 July) at which this behavioral change occurred was approximately local twilight. The cod may have begun nocturnal foraging on prey (Pandalus borealis) present in the area (DeBlois and Rose, 1995). Thus the cue for onshore migration continued, but the fish changed behavior in response to another stimulus (Helfman, 1993).

In general, the sonically-tagged cod behaved as members of the shoal, in that their net movement was similar to that of the shoal itself (Pitcher, 1983; Pitcher and Parrish, 1993). The tagged cod all began moving at the same time and in the same general direction as the shoal commenced its inshore migration on 2 July (Fig. 2 in Rose et al., 1995). The tagged fish also stopped moving at the same time the shoal stopped, probably to feed on shrimp (DeBlois and Rose, 1995).

Notwithstanding the overall similarity in the movements of the tagged fish and the shoal, there were also differences. During the period of directed onshore movement, the swimming speeds of the tagged fish $\left(0.14-0.24 \mathrm{~m} \mathrm{~s}^{-1} ; 0.25-0.43 \mathrm{BL} \mathrm{s}^{-1}\right)$ exceeded the mean speeds of the entire shoal $\left(0.08 \mathrm{~m} \mathrm{~s}^{-1}, 0.18\right.$ $\mathrm{BL} \mathrm{s}^{-1}$ swimming speed; $0.13 \mathrm{~m} \mathrm{~s}^{-1}$ ground speed; from Rose et al., 1995). We note that the tagged fish (56-57 cm in length) were among the largest cod in the shoal (interquartile range 42-48 cm; Rose, 1993). The faster speeds of the tagged fish are consistent with body size to swimming speed theory (e.g. Wardle, 1977; He, 1991) and with the observation that larger fish were on average positioned at the front of this shoal (DeBlois and Rose, 1996). There was also some diversity among the swimming speeds of the tagged fish. The tagged fish that was in poorer condition swam faster than the other two. DeBlois and Rose (1996) noted that while on average the larger cod led this aggregation, not all larger fish were at the front. They suggested that hunger (condition) might play a role in position, with fish in poorer condition taking the lead, then dropping back to the shoal center when satiated. Such hunger-driven shoal structure has been demonstrated in shoaling herring (Robinson and Pitcher, 1989) and roach (Krause et al., 1992; Krause, 1993).

\section{Acknowledgements}

We thank W. Bailey for assistance at sea. S. Narayanan and E. Colbourne provided the BB1 current meter data. K. Forward and K. Smedbol assisted with graphics. This study was funded by the Natural Sciences and Engineering Research Council of Canada (NSERC), National Sea Products and Fishery Products International under NSERC's Research Partnerships Program. Funding for G.A.R. and B.deY. was provided by the Ocean Production Enhancement Network (OPEN), one of the Networks of Centres of Excellence supported by the Government of Canada.

\section{References}

Arnold, G.P., 1974. Rheotropism in fishes. Biological Reviews of the Cambridge Philosophical Society 49, 515-576.

Arnold, G.P., 1981. Movements of fish in relation to water currents. In: Aidley, D.J. (Ed.), Animal Migration: Society for Experimental Biology Seminar Series 13. Cambridge University Press, Cambridge, pp. 55-79.

Arnold, G.P., Holford, B.H., 1995. A computer simulation model for predicting rates and scales of movement of demersal fish on the European continental shelf. ICES J. Mar. Sci. 52, 981-990.

Arnold, G.P., Metcalfe, J.D., 1989. Acoustic telemetry: progress and potential in understanding fish behavior. Proc. Inst. Acoust. 11, 96-103.

Arnold, G.P., Metcalfe, J.D., 1995. Seasonal migrations of plaice (Pleuronectes platessa) through the Dover Strait. Mar. Biol. 127, 151-160.

Arnold, G.P., Greer Walker, M., 1992. Vertical movements of cod (Gadus morhua L.) in the open sea and hydrostatic function of the swimbladder. ICES J. Mar. Sci. 49, 357-372. 
Arnold, G.P., Greer Walker, M., Emerson, L.S., Holford, B.H., 1994. Movements of cod (Gadus morhua L.) in relation to tidal streams in the southern North Sea. ICES J. Mar.Sci. 51, 207232.

Colbourne, E., deYoung, B., Narayanan, S., Helbig, J., 1997. Comparison of hydrography and circulation on the Newfoundland Shelf during 1990-1993 with the long term mean. Can. J. Fish. Aquat. Sci. 54, 68-80.

DeBlois, E.M., Rose, G.A., 1995. Effect of foraging activity on the shoal structure of cod (Gadus morhua). Can. J. Fish. Aquat. Sci. 52, 2377-2387.

DeBlois, E.M., Rose, G.A., 1996. Cross-shoal variability in the feeding habits of migrating Atlantic cod (Gadus morhua). Oecologia 108, 192-196.

Harden Jones, F.R., 1968. Fish Migration. Arnold, London.

Harden Jones, F.R., Scholes, P., 1985. Gas secretion and resorption in the swimbladder of the cod Gadus morhua. J. Comp. Physiol. B 155, 319-331.

Hawkins, A.D., Urquhart, G.G., 1983. Tracking fish at sea. In: MacDonald, A.G., Priede, I.G. (Eds.), Experimental Biology at Sea. Academic Press, London, pp. 103-166.

He, P., 1991. Swimming endurance of the Atlantic cod, Gadus morhua L., at low temperatures. Fish. Res. 12, 65-73.

Helfman, G.S., 1993. Fish behavior by day, night and twilight. In: Pitcher, T.J. (Ed.), Behavior of Teleost Fishes. Chapman and Hall, London, pp. 479-512.

Krause, J., 1993. Positioning behavior in fish shoals: a cost-benefit analysis. J. Fish. Biol. 43 (suppl. A), 309-314.

Krause, J., Buman, D., Todt, D., 1992. Relationship between the position preference and nutritional state of individuals in schools of juvenile roach (Rutilus rutilus). Behav. Ecol. Sociobiol. 30, 177-180.

Lear, W.H., Green, J.M., 1984. Migration of the "northern" Atlantic cod and the mechanisms involved. In: McCleave, J.D., Arnold, G.P., Dodson, J.J., Neill, W.H. (Eds.), Mechanisms of Migration in Fishes. Plenum Press, New York, pp. 309-315.

MacLennan, D.N., Simmonds, E.J., 1992. Fisheries Acoustics. Chapman and Hall, London.

Metcalfe, J.D., Arnold, G.P., Webb, P.J., 1990. The energetics of migration by selective tidal stream transport: an analysis for plaice tracked in the southern North Sea. J. Mar. Biol. Assn. UK 70, 149-162.

Metcalfe, J.D., Arnold, G.P., 1997. Tracking fish with electronic tags. Nature 387, 665-666.

Narayanan, S., 1994. Current meter observations from Hamilton Bank and the northeast Newfoundland Shelf, 1990-1993. Can. Tech. Rep. Hydrogr. Ocean Sci. 157, 184.

Pitcher, T.J., 1983. Heuristic definitions of shoaling behavior. Anim. Behav. 31, 611-613.

Pitcher, T.J., Parrish, J.K., 1993. Functions of shoaling behavior in teleosts. In: Pitcher, T.J. (Ed.), Behavior of Teleost Fishes. Chapman and Hall, London, pp. 363-439.

Pitcher, T.J., Wyche, C.J., Magurran, A.E., 1982. Evidence for positioning preferences in schooling mackerel. Anim. Behav. 30, 932-934.

Robinson, C.M., Pitcher, T.J., 1989. Hunger as a promoter of different behaviors within a shoal of herring, Clupea harengus L.. J. Fish Biol. 35, 459-460.

Rose, G.A., 1993. Cod spawning on a migration highway in the north-west Atlantic. Nature 366, 458-461.

Rose, G.A., Kulka, D.W., 1999. Hyper-aggregation of fish and fisheries: how CPUE increased as the northern cod declined. Can. J. Fish. Aquat. Sci. (in press).

Rose, G.A., deYoung, B., Colbourne, E.B., 1995. Cod (Gadus morhua L.) migration speeds and transport relative to currents on the northeast Newfoundland Shelf. ICES J. Mar. Sci. 52, 903-914.

Templeman, W., 1965. Some instances of cod and haddock behavior and concentrations in the Newfoundland and Labrador areas in relation to food. ICNAF Special Publ., vol. 6, pp. 449461.

Tytler, P., Machin, D., Holliday, F.G.T., Priede, I.G., 1978. A comparison of the patterns of movement between indigenous and displaced brown trout (Salmo trutta L) in a small shallow loch. Proc. R. Soc. Edinburgh, vol. 76B, pp. 245-268.

Wardle, C.S., 1977. Effects of size on the swimming speeds of fish. In: Pedley, T.J. (Ed.), Scale Effects in Animal Locomotion. Academic Press, London, pp. 299-313.

Weihs, D., 1978. Tidal stream transport as an efficient method for migration. J. du Conseil 38, 92-99. 